\title{
Sunflower Mega-Environments in Serbia Revealed By GGE Biplot Analysis
}

\author{
Igor Balalić • Gordana Branković •Miroslav Zorić • Vladimir Miklič • \\ Siniša Jocić • Gordana Šurlan-Momirović
}

\author{
received: 18 June 2013, accepted: 9 October 2013 \\ published online: 5 November 2013 \\ (c) 2013 IFVC \\ doi: $10.5937 /$ ratpov $50-4041$
}

\begin{abstract}
Summary: Sunflower mega-environment analysis was conducted for the grain yield data of 20 hybrids and 19 test locations during 2006, and 20 hybrids and 16 test locations during 2007. Combined data included 15 hybrids and 9 test locations common for both years and it was analyzed as balanced experiment. The analysis of variance components showed that hybrid by location interaction explained 2.74, 5.8, and 3.72 times more variation than hybrid, for grain yield, for 2006, 2007, combined data, respectively, and indicated potential mega-environment existence. Our results showed the existence of two mega-environments in Serbia sunflower growing region: (1) Kula Vitovnica, Aleksa Šantić, Sombor and (2) Rimski Šančevi, Kikinda. It has been concluded that if we want promising sunflower hybrids to be optimally used, they should be cropped differently for the two determined mega-environments.

Key words: genotype $\times$ environment interaction, grain yield, hybrids, mega-environment, site location, sites regression, sunflower
\end{abstract}

\section{Introduction}

Sunflower (Helianthus annuus L.) is the major cultivated oil crop in Serbia. According to FAOSTAT data for 2011 sunflower seed harvesting area in Serbia was 174,270 ha and production reached 432,020 t (FAO 2011).

The most important directions of sunflower hybrids development are increasing grain yield and oil content, acceptor of assimilative, harvest index, resistance to prevalent diseases and insect pests, and also optimization of architecture, which should provide in an intensive agronomic practices increase of plants number per unit area (Skoric et al. 2000). The commercial sunflower hybrids in dry seeds contain $48-50 \%$ of oil, $16-20 \%$ of proteins, $12.9-32 \%$ of cellulose and $1.8-4.9 \%$ of minerals (Dijanovic 2003). The linoleic acid is the important content of sunflower oil, essential for the human nutrition, regarding the fact that it

\section{G. Branković* • G. Šurlan-Momirović}

University of Belgrade, Faculty of Agriculture, Department of Genetics, Plant Breeding and Seed Science, 6 Nemanjina, 11080 Belgrade - Zemun, Serbia

e-mail: bgordana@agrif.bg.ac.rs

I. Balalić• M. Zorić • V. Miklič $\bullet$ S. Jocić

Institute of Field and Vegetable Crops, 30 Maksima Gorkog, 21000 Novi Sad, Serbia cannot be synthesized by the human metabolism (Stankovic 2005). It is desirable quality for hybrids to show the good adaptability and stability, and these issues are interrelated with the level of the genotype $\times$ environment interaction (GEI).

In multi-environment trial (MET), cultivars and lines are usually tested over several locations and time period (Yan et al. 2001). Plant breeding aims to decrease GEI and error variance of phenotype values (Moreno-Gonzales et al. 1997). GEI, as a component of phenotype variability reduces interdependence between phenotype and genotype (Comstock \& Moll 1963), causes heritability and genetic progress from selection to decrease (Kang, 2002) and hinders identification of superior genotypes in METs (Shaffi \& Price 1998). The increase of GEI magnitude expands number of test sites, which affects breeding program efficiency (Kang \& Magari, 1995).

Obstructive crossover interaction (COI) can become beneficial if environments impact on genotypes is dissected, and if the environmental groupings with insignificant COI are determined (Goyal et al., 2011). The sites regression model

Acknowledgements:

This work was supported by the Ministry of Education, Science and Technological Development of the Republic of Serbia (Research Grant: TR-31025). 
(SREG) (Crossa \& Cornelius, 1997) has feature of grouping locations within which is inconsiderable genotypic rank change (Crossa et al. 2002). SREG biplot shows the "which-won-where" pattern of the dataset, crossover GEI, mega-environment differentiation, specific adaptation, etc. (Yan \& Tinker 2006). With regard to GEI two conditions must be fulfilled in order to differentiate megaenvironments. Crossover genotype $\times$ location interaction must be confirmed with repeatable patterns over the years (Cooper \& Delacy 1994), and also different superior genotypes must be "winners" in different sites (Gauch \& Zobel 1996).

The scientific aims of this research were to (i) identify groups of locations with low crossover hybrid $\times$ location interaction for single years; and (ii) determine mega-environment differentiation for the sunflower growing region in Serbia.

\section{Materials and Methods}

Sunflower hybrids tested in the multienvironment trial originated from the collection of Oil Crops Department of the Institute of Field and Vegetable Crops, Novi Sad, Serbia (Tab. 1, Tab. 2). Sunflower grain yield trials were performed by Oil Crops Department of the Institute of Field and Vegetable Crops during 2006 and 2007 in Serbia. Sunflower multi-environment trial included 20 hybrids and 19 test locations, 20 hybrids and 16 test locations, during 2006 and 2007, respectively. Combined data included 15 hybrids and 9 test locations common for both years analyzed as balanced experiment. Geographic position of test locations used in sunflower testing network in Serbia is given in Figure 1.

Table 1. Names, types and codes of the sunflower hybrids tested

\begin{tabular}{|c|c|c|c|c|}
\hline Hybrid name & Type of hybrid & Code for 2006. & Code for 2007. & $\begin{array}{c}\text { Code for 2006- } \\
2007 .\end{array}$ \\
\hline NS-H-111 & standard & 1 & 1 & 1 \\
\hline Velja & standard & 2 & 2 & 2 \\
\hline Krajišnik & standard & 3 & 3 & 3 \\
\hline Olivko & highlyoleic & 4 & 4 & 4 \\
\hline NS-H-45 & standard & 5 & 5 & 5 \\
\hline Baća & standard broomrape resistant & 6 & 6 & 6 \\
\hline Vranac & protein & 7 & 7 & 7 \\
\hline Pobednik & standard & 8 & 8 & 8 \\
\hline Sremac & standard downy mildew resistant & 9 & 9 & 9 \\
\hline Somborac & standard & 10 & 10 & 10 \\
\hline Šumadinac & standard broomrape resistant & 11 & 11 & 11 \\
\hline Kazanova & standard & 12 & 12 & 12 \\
\hline Rimi & herbicide tolerant & 13 & 13 & 13 \\
\hline Bačvanin & standard broomrape resistant & 14 & 14 & 14 \\
\hline Perun & standard broomrape resistant & 15 & 15 & 15 \\
\hline Cepko & protein & 16 & - & - \\
\hline Stig & medium early oil & 17 & - & - \\
\hline Vitalko & herbicide tolerant & 18 & - & - \\
\hline Dukat & for stubble crop sowing & 19 & - & - \\
\hline Banaćanin & medium early oil & 20 & - & - \\
\hline Plamen & standard downy mildew resistant & - & 16 & - \\
\hline Duško & standard downy mildew resistant & - & 17 & - \\
\hline Branko & standard broomrape resistant & - & 18 & - \\
\hline Novosađanin & standard broomrape resistant & - & 19 & - \\
\hline Oliva & highlyoleic & - & 20 & - \\
\hline
\end{tabular}


Table 2. Locations, codes and average grain yield of sunflower hybrids at the test locations.

\begin{tabular}{|c|c|c|c|c|c|c|c|}
\hline Location & Code & Year & $\begin{array}{c}\mathrm{GY} \\
\left(\mathrm{t} \mathrm{ha}^{-1}\right)\end{array}$ & Location & Code & Year & $\begin{array}{c}\mathrm{GY} \\
\left(\mathrm{t} \mathrm{ha}^{-1}\right)\end{array}$ \\
\hline Zaječar & $\mathrm{ZA}$ & $\begin{array}{l}2006 \\
2007\end{array}$ & $\begin{array}{l}4.208 \\
1.938\end{array}$ & Lazarevo & LA & $\begin{array}{c}2006 \\
-\end{array}$ & $\begin{array}{c}2.506 \\
-\end{array}$ \\
\hline Kula Vitovnica & $\mathrm{KV}$ & $\begin{array}{l}2006 \\
2007\end{array}$ & $\begin{array}{l}2.064 \\
2.343\end{array}$ & Srpski Itebej & SI & $\begin{array}{c}2006 \\
-\end{array}$ & $\begin{array}{c}2.656 \\
-\end{array}$ \\
\hline Kragujevac & KG & $\begin{array}{l}2006 \\
2007\end{array}$ & $\begin{array}{l}1.754 \\
2.098\end{array}$ & Pančevo & $\mathrm{PA}$ & $\begin{array}{c}2006 \\
-\end{array}$ & $\begin{array}{c}2.537 \\
-\end{array}$ \\
\hline Rimski Šančevi & RS & $\begin{array}{l}2006 \\
2007\end{array}$ & $\begin{array}{l}3.316 \\
3.880\end{array}$ & Kovin & $\mathrm{KO}$ & $\begin{array}{c}2006 \\
-\end{array}$ & $\begin{array}{c}2.440 \\
-\end{array}$ \\
\hline Bačka Topola & BT & $\begin{array}{l}2006 \\
2007\end{array}$ & $\begin{array}{l}3.070 \\
3.910\end{array}$ & Beška & $\mathrm{BE}$ & $\begin{array}{c}2006 \\
-\end{array}$ & $\begin{array}{c}3.051 \\
-\end{array}$ \\
\hline Sombor & SO & $\begin{array}{l}2006 \\
2007\end{array}$ & $\begin{array}{l}3.100 \\
3.113\end{array}$ & Požarevac & $\mathrm{PO}$ & $\begin{array}{c}2006 \\
-\end{array}$ & $\begin{array}{c}1.836 \\
-\end{array}$ \\
\hline Aleksa Šantić & AS & $\begin{array}{l}2006 \\
2007\end{array}$ & $\begin{array}{l}2.736 \\
2.332\end{array}$ & Kula & KU & 2007 & 2.962 \\
\hline Kikinda & KI & $\begin{array}{l}2006 \\
2007\end{array}$ & $\begin{array}{l}3.030 \\
3.409\end{array}$ & Bačko Gradište & $B G$ & $\begin{array}{c}- \\
2007\end{array}$ & $\begin{array}{c}- \\
3.629\end{array}$ \\
\hline Vršac & VS & $\begin{array}{l}2006 \\
2007\end{array}$ & $\begin{array}{l}2.550 \\
2.406\end{array}$ & Đurđin & DU & 2007 & 2.500 \\
\hline Bačka Palanka & $\mathrm{BP}$ & $\begin{array}{c}2006 \\
-\end{array}$ & $\begin{array}{c}2.512 \\
-\end{array}$ & Zrenjanin & ZR & 2007 & $\begin{array}{c}- \\
2.421\end{array}$ \\
\hline Bečej & $\mathrm{BC}$ & $\begin{array}{c}2006 \\
-\end{array}$ & $\begin{array}{c}3.168 \\
-\end{array}$ & Neuzina & $\mathrm{NZ}$ & $\begin{array}{c}- \\
2007\end{array}$ & 2.633 \\
\hline Subotica & SU & $\begin{array}{c}2006 \\
-\end{array}$ & $\begin{array}{c}3.294 \\
-\end{array}$ & Neštin & NS & $\begin{array}{c}- \\
2007\end{array}$ & 3.706 \\
\hline Aradac & $\mathrm{AR}$ & $\begin{array}{c}2006 \\
-\end{array}$ & $\begin{array}{c}2.107 \\
-\end{array}$ & Negotin & NE & $\begin{array}{c}- \\
2007\end{array}$ & $\begin{array}{c}- \\
1.143\end{array}$ \\
\hline
\end{tabular}

GY - grain yield

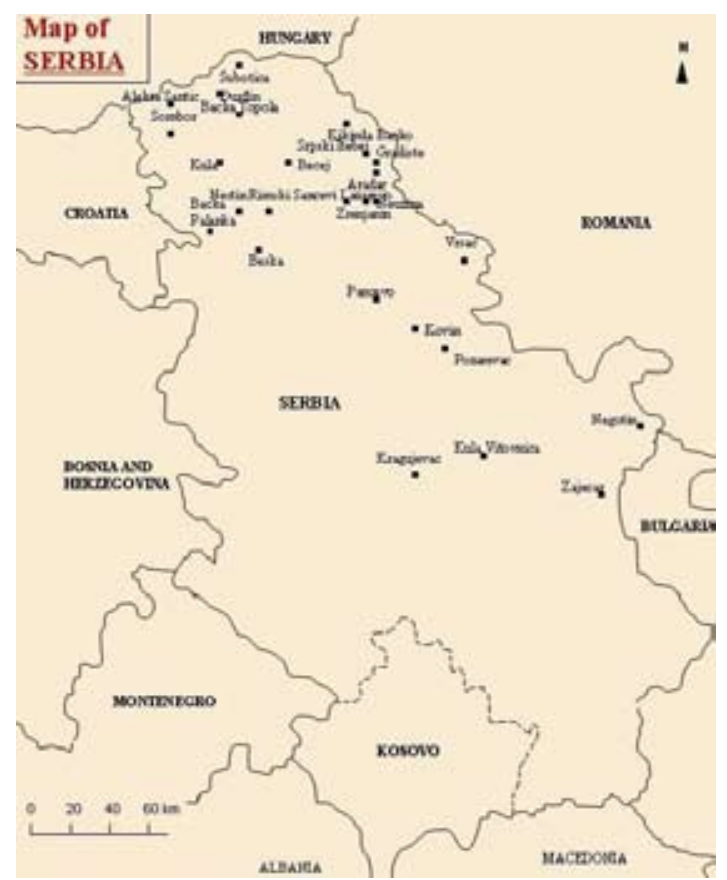

Figure 1. Geographic position of test locations used in sunflower testing network in Serbia. 
The mean grain yield $\left(\mathrm{t} \mathrm{ha} \mathrm{a}^{-1}\right)$ was measured from the trials performed in a randomized complete block design with four replications. Elementary plot size was $13.3 \mathrm{~m}^{2}(0.7 \times 0.25$ $\times 76)$ and two middle rows were used for analysis, with border plants excluded. Standard agronomic practices recommended for sunflower cropping were applied. Grain yield was measured as grain mass for each elementary plot and grain yield $\left(\mathrm{t} \mathrm{ha}^{-1}\right)$ with $11 \%$ moisture was assessed.

Möhring and Piepho (2009) procedure was used as initial step in the analysis of variance components. GGE biplot was produced using the sites regression model (Crossa \& Cornelius 1997) with R 2.9.0. statistical program (R Development Core Team 2009).

\section{Results}

The analysis of variance components for grain yield showed that location explained $72.54 \%$, $90.00 \%, 85.47 \%$ of the G + GE variation for 2006 , 2007, and combined data, respectively (Tab. 3). The variation explained with hybrid by location interaction were 2.74, 5.8, 3.72 times greater than variation due to hybrid effect, for 2006 network trial, 2007 network trial, and combined data, respectively (Tab. 3).

Primary biplot interpreted $59.1 \%$ of total G + GE grain yield variation in 2006 (Fig. 2). Hybrids on the vertices of the polygon for 2006 data were G1, G9, G5, G6, G7, G16, G19, and G18. The first sector contained locations BT, AS, BC, SO, KG, SI, $\mathrm{VS}, \mathrm{KV}, \mathrm{PO}, \mathrm{AR}$ with hybrid G1 being the winner.

Table 3. Variance components ( \pm standard error) of two-way random model for sunflower multi-envionment trials.

\begin{tabular}{lcccccc}
\hline Source of variation & 2006 & $\%$ & 2007 & $\%$ & Combined data & $\%$ \\
\hline Hybrid & $0.035 \pm 0.013^{\dagger}$ & 7.34 & $0.010 \pm 0.004$ & 1.47 & $0.018 \pm 0.008$ & 3.08 \\
Location & $0.346 \pm 0.117$ & 72.54 & $0.612 \pm 0.224$ & 90.00 & $0.500 \pm 0.173$ & 85.47 \\
$\begin{array}{l}\text { Hybrid by location } \\
\text { interaction }\end{array}$ & $0.096 \pm 0.007$ & 20.12 & $0.058 \pm 0.005$ & 8.53 & $0.067 \pm 0.006$ & 11.45 \\
\hline
\end{tabular}

${ }^{\dagger}$ standard error

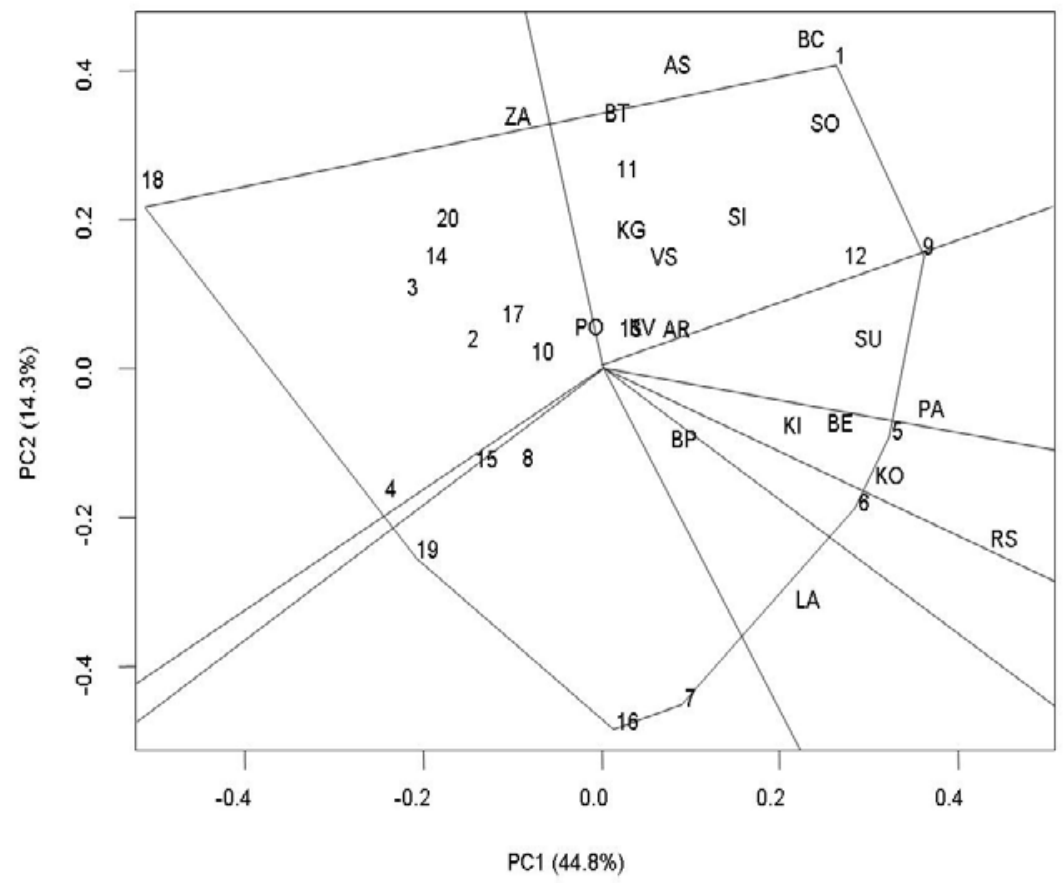

Figure 2. Sites regression biplot ("which-won-where" view) for grain yield of sunflower multi-environment trial in 2006. The details for locations and genotypes are given in Table 1 and Table 2. 


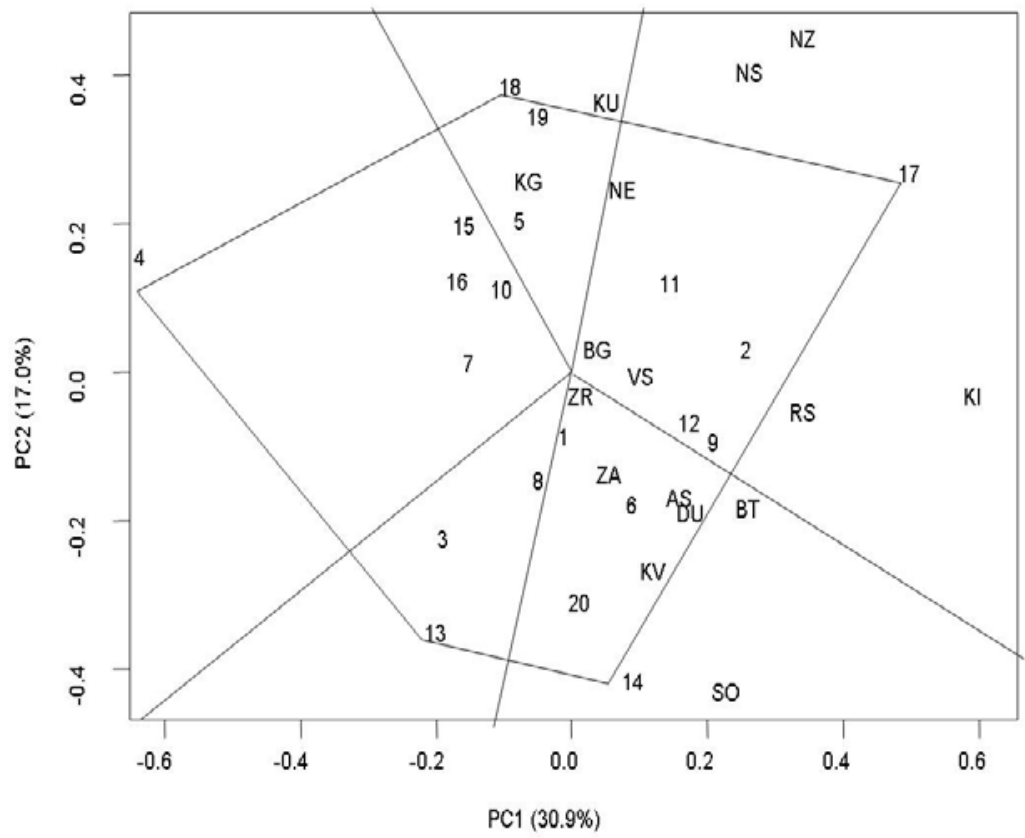

Figure 3. Sites regression biplot ("which-won-where" view) for grain yield of sunflower multi-environment trial in 2007. The details for locations and genotypes are given in Table 1 and Table 2.

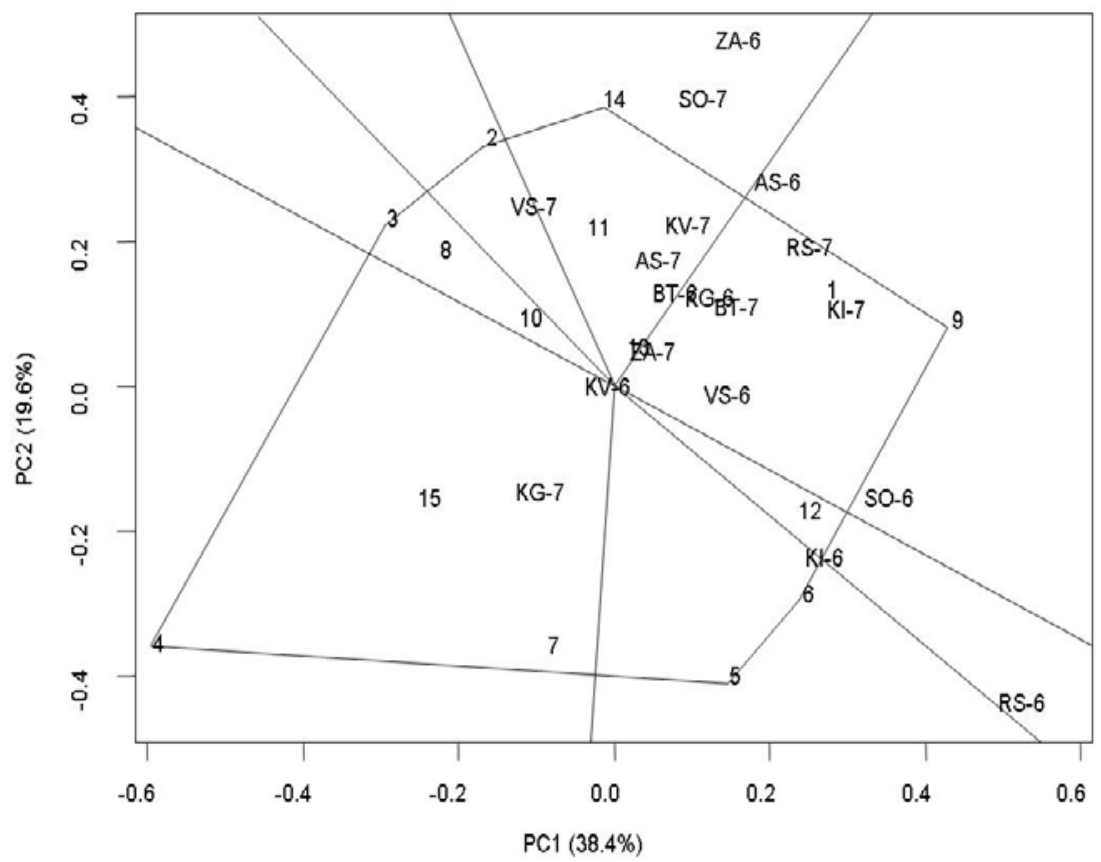

Figure 4. Sites regression biplot ("which-won-where" view) for grain yield of sunflower multi-environment trial-combined data. The details for locations and genotypes are given in Table 1 and Table 2. 
Location PO was on the perpendicular line which was equality line between G1 and G18, and shared these two genotype as the winning ones. The second sector contains locations $S U$ and PA with hybrid G9 being the winner. The third sector contains locations $\mathrm{KI}, \mathrm{BE}, \mathrm{KO}$, RS with hybrid G5 being the winner. The forth sector contains locations $\mathrm{BP}$ and LA with hybrid G7 being the winner. The winning genotype for the ZA locations is G18. G18, G4 and G19 were far away from the rest of the locations on the biplot, and they had insufficient yield at all locations. Mega-environments are outlined by different superior genotypes (Gauch and Zobel 1997), and according to the results showed with Figure 2, it was suggested the existence of one larger mega-environment for sunflower growing region in Serbia, NS-H-111-winning niche and three small ones, NS-H-45-winning niche, Vranacwinning niche, Sremac-winning niche.

Primary biplot explained $47.9 \%$ of total G + GE grain yield variance in 2007 (Fig. 3). Hybrids on the vertices of the polygon for 2007 data were G17, G14, G13, G4 and G18. The first sector contains locations NZ, NS, NE, BG, VS, KI, RS with hybrid G17 being the winner. The second sector contains locations ZR, ZA, AS, DU, KV, SO, BT with hybrid G14 being the winner. The third sector contains test locations $\mathrm{KG}$ and $\mathrm{KU}$, and winning hybrid for them was G18. G13 and G4 were isolated from the rest of the locations, and they had inferior grain yield at all locations. Based on the results showed with Figure 3 it was suggested the existence of three mega-environments for sunflower growing region in Serbia, Duško-winning niche, Bačvaninwinning niche and Branko-winning niche.

Primary biplot outlined $58.0 \%$ of total G $+\mathrm{GE}$ grain yield variance in combined analysis (Fig. 4). Hybrids on the vertices of the polygon for 20062007 data were G9, G6, G5, G4, G3, G2 and G14. The first sector contained AS-6, RS-7, BT-7, KG-6, ZA-7, VS-6, KI-7, SO-6 with G9 being the winner. The second sector contained locations VS-7, BT-6, ZA-6, SO-7, KV-7, AS-7 with hybrid G14 being the winner. The third sector contained KI- 6 and RS-6 with hybrid G6 being the winner. Location KG-7 was excluded from these three sectors and winning hybrid for it was G4 (Olivko). BT-6 and ZA-7 were on the perpendicular line which was equality line between G14 and G9, and shared these two hybrids as the winning ones. Location VS-7 was on the perpendicular line which was equality line between G2 and G14, which both represented winning hybrids in them. In addition, KI-6 was on the perpendicular line between G6 and G5, and both of them were the winners in it. Location KV-6 was in the origin position on the biplot and showed average mean grain yield of all tested locations, and hybrids on the polygon vertices were equally successful in it. G4 was the winner hybrid in the KG-7 location, but at all other sites performed poorly, because its marker was isolated from the rest of the test locations.

\section{Discussion}

SREG biplot analysis was successfully used in various investigations for mega-environment exploration (Yan et al. 2000, Butron et al. 2004, Kang et al. 2005, Casanoves et al. 2005, Malvar et al. 2005, Preciado-Ortiz et al. 2006, Fan et al. 2007, Mohammadi et al. 2010 and Goyal et al. 2011). The comparison of GGE biplot patterns across years and combined data is important because exclusion or inclusion of locations offers more precise evaluations of mega-environment differentiation and of genotype location interaction.

The analysis of variance components showed that the largest portion of the grain yield variance in both tested years and combined data is due to location, and as an unrelated to hybrid assessment and mega-environments (Fox and Rosielle 1982), justified the use of the SREG model as suitable for MET interpretation. The large GEI, relative to $G$ showed by variance component analysis, for both testing networks and combined data, indicated distinctive mega-environments. If genotype $\times$ environment interaction (GEI) effect is although statistically significant rather small to main genotype effect $(G)$, it decreases advances of breeding for specific adaptation. Only repeatable (by years) GEI can be used for selection and breeding of specifically adapted genotypes (Babić et al. 2010), or yield stability can be utilized through selection of widely adapted genotypes, with small frequency of low yields (Ceccarelli 1994). The yield gain from GEI utilization within the state can help to increase competitiveness of national seed companies in comparison to international ones.

The target region division into significant megaenvironments is only possible way of interaction exploitation (Yan \& Tinker 2006), because megaenvironment definition assumes homogenic location groups with minimized interaction. Our results showed the existence of two megaenvironments in Serbia sunflower growing region based on grain yield data analyzed by yearly SREG biplot analyses, and by combined data SREG biplot analysis, which included 9 of 26 locations tested. The first mega-environment includes KV, AS and SO and the second RS and KI (Fig. 2, Fig. 3, Fig. 4 ), and these clusters of locations were consistently 
found together in the same sector through all three biplots.

Similar climatic conditions averaged for two years were recorded for the period AprilSeptember, the vegetation season in Serbia, for the locations constituting two different megaenvironments. Kula Vitovnica is on the altitude of $220 \mathrm{~m}$ with relative humidity (rh) $-71.5 \%$, sunshine hours $(\mathrm{sh})-264.9$, sum of rainfall $(\mathrm{pp})$ $-55.1 \mathrm{~mm}$, maximum temperature $(\mathrm{mxt})-26.9^{\circ} \mathrm{C}$, minimum temperature (mnt) $-11,3^{\circ} \mathrm{C}$ and mean temperature $(\mathrm{mt})-18.9^{\circ} \mathrm{C}$. Aleksa Santic is on the altitude of $120 \mathrm{~m}$ with $\mathrm{rh}-76.2 \%$, sh - 289.8, pp $-60.4 \mathrm{~mm}, \mathrm{mxt}-26.3^{\circ} \mathrm{C}, \mathrm{mnt}-12.3^{\circ} \mathrm{C}$ and $\mathrm{mt}$ $19.8^{\circ} \mathrm{C}$. Sombor is on the altitude of $90 \mathrm{~m}$ with $\mathrm{rh}$ - 60.9\%, sh - 277.8, pp - $66.4 \mathrm{~mm}$, mxt $-26.0^{\circ} \mathrm{C}$, $\mathrm{mnt}-12.8^{\circ} \mathrm{C}$ and $\mathrm{mt}-19.3^{\circ} \mathrm{C}$. Rimski Šancevi is on the altitude of $84 \mathrm{~m}$ with $\mathrm{rh}-68.5 \%$, sh -280.4 , $\mathrm{pp}-68.5 \mathrm{~mm}, \mathrm{mxt}-25.6^{\circ} \mathrm{C}$, $\mathrm{mnt}-13.0^{\circ} \mathrm{C}$ and $\mathrm{mt}-$ $19.2^{\circ} \mathrm{C}$. Kikinda is on the altitude of $73 \mathrm{~m}$ with $\mathrm{rh}$ 65.3\%, sh - 284.4, pp - $61.3 \mathrm{~mm}, \mathrm{mxt}-25.6^{\circ} \mathrm{C}$, mnt $-13.5^{\circ} \mathrm{C}$ and $\mathrm{mt}-19.5^{\circ} \mathrm{C}$. Soil type was chernozem for all locations in the above-mentioned megaenvironments.

Locating hybrids in different sectors implied GEI in this study, and registered COI interactions made four other locations in the balanced set excluded as not belonging to these two confirmed megaenvironments, based on two-years MET data with 25 sunflower hybrids. For the rest of 17 locations included in single year's analysis assumptions have been made, but they need confirmation by additional testing.

\section{Conclusions}

GGE biplot analysis of sunflower hybrid $x$ environment interaction is significant for breeding, hybrids evaluations and recommendation of favorable varieties in Serbia. First, if we want the promising sunflower hybrids to be optimally used for prevalent climatic and abiotic conditions, they should be cropped at the two different determined mega-environments. Second, SREG biplot techniques offered us opportunity for identification and utilization of general and specific adaptation of perspective sunflower hybrids for heterogeneous agro-ecological areas in Serbia, which was already applied in commercial practice.

\section{References}

Babić, V., Babić, M., Ivanović, M., Kraljević-Balalić, M., \& Dimitrijević, M. (2010). Understanding and utilization of genotypeby-environment interaction in maize breeding. Genetika-Belgrade, 42(1), 79-90. doi:10.2298/GENSR1001079B

Butron, A., Velasco, P., Ordas, A., \& Malvar, R.A. (2004). Yield Evaluation of Maize Cultivars across Environments with Different Levels of Pink Stem Borer Infestation. Crop Sci., 44(3), 741-747. doi:10.2135/cropsci2004.0741

Casanoves, F., Baldessari, J., \& Balzarini, M. (2005). Evaluation of multienvironment trials of peanut cultivars. Crop Sci., 45, 18-26.

Ceccarelli, S., Erskine, W., Hamblin, J., \& Grando, S. (1994). Genotype by Environment Interaction and International Breeding Programmes. Experimental Agriculture, 30(02), 177-187. doi:10.1017/S0014479700024121

Comstock, R.E., \& Moll, R.H. (1963). Genotype - environment interactions. In: W.D. Hanson \& H.F. Robinson (Eds.),Symposium on Statistical Genetics and Plant Breeding. Washington: National Academy of Sciences- National Research Council.164-196.

Cooper, M., \& Delacy, I.H. (1994). Relationships among analytical methods used to study genotypic variation and genotype-by-environment interaction in plant breeding multienvironment experiments. Theoretical and Applied Genetics, 88(5), 561-572. doi:10.1007/BF01240919

Crossa, J., \& Cornelius, P.L. (1997). Sites regression and shifted multiplicative model clustering of cultivar trial sites under heterogenity of error variances. Crop Sci., 37, 405-415.

Crossa, J., Cornelius, P.L., \& Yang, W. (2002). Biplots of linearbilinear models for studying crossover genotype-environment interaction. Crop Sci., 42, 619-633.

Dijanovic, D. (2003). Fenotipska stabilnost perspektivnih genotipova proteinskog suncokreta (Helianthus annuus L.). Novi Sad: Poljoprivredni fakultet.

Fan, X., Kang, M.S., Chen, H., Zhang, Y., Tan, J., \& Xu, C. (2007). Yield Stability of Maize Hybrids Evaluated in MultiEnvironment Trials in Yunnan, China. Agronomy Journal, 99(1), 220-228. doi:10.2134/agronj2006.0144

FAO. (2011). FAOSTAT [Online]. Retrieved from http://faosta.fao.org

Fox, P.N., \& Rosielle, A.A. (1982). Reference sets of genotypes and selection for yield in unpredictable environments.Crop Sci., 22, 1171-1174.

Gauch, H.G., \& Zobel, R.W. (1996). AMMI analysis of yield trials. In M.S. Kang \& H.G. Gauch (Eds.), Genotype by Environment Interactions. (pp. 1-40). Boca Raton, FL: CRS Press.

Goyal, A., Beres, B.L., Randhawa, H.S., Navabi, A., Salmon, D.F., \& Eudes, F. (2011). Yield stability analysis of broadly adaptive triticale germplasm in southern and central Alberta, Canada, for industrial end-use suitability.Can. J. Plant Sci., 91, 125-135.

Kang, M.S., \& Magari, R. (1995). New developments in selecting for phenotypic stability in crop breeding. In M.S. Kang \& H.G. Gauch (Eds.), Genotype by Environment Interactions. (pp. 1-14). Boca Raton, FL: CRC Press.

Kang, M.S. (2002). Genotype-environment interaction: Progress and prospects. In M.S. Kang (Ed.), Quantitative genetics. Genomics and plant breeding. (pp. 221-243). New York: CAB International Publishing.

Kang, M.S., Aggarwal, V.D., \& Chirwa, R.M. (2005). Adaptability and stability of bean cultivars as determined via yieldstability statistic and GGE biplot analysis. J. Crop Improv, 15, 97-120.

Malvar, R.A., Revilla, A., Butron, B., \& i dr., (2005). Performance of crosses among french and spanish maize populations across environments. Crop Sci., 45(3), 1052-1057. doi:10.2135/ cropsci2004.0301 
Möhring, J., \& Piepho, H.P. (2009). Comparison of weighting methods in two-stage analysis of plant breeding trials.Crop Sci., 49, 1977-1988.

Mohammadi, R., Haghparast, R., Amri, A., \& Ceccarelli, S. (2010). Yield stability of rainfed durum wheat and GGE biplot analysis of multi-environment trials. Crop and Pasture Science, 61(1), 92-101. doi:10.1071/CP09151

Moreno-Gonzalez, J., Crossa, J., \& Cornelius, P.L. (1997). Additive main effects and multiplicative interaction model. I. Variance components for predicting cell means. Crop Sci., 43, 1967-1965.

Preciado-Ortiz, R., Guerrero, R., Ortega, A., Terron, A., Crossa, J., Cordova, H., . . Cervantes, E. (2006). Identification of superior quality protein maize hybrids for different megaenvironments using the biplot methodology. Maydica, 51, 451-461.

R Development Core Team. (2010). A language and environment for statistical computing. Retrieved from www.Rproject.org
Shafi, B., \& Price, W.J. (1998). Analysis of genotype-by-environment interaction using the additive main effects and multiplicative interaction model and stability estimates. J. Agric. Biol. Environ. Stat, 3(3), 335-345. doi:10.2307/1400587

Škorić, D., Jocić, S., \& Molnar, I. (2000). General (GCA) and specific (SCA) combining abilities in sunflower. In: Proc. 15th Internat. Sunflow. Confer., 12. -15. June, Toulouse. 23-29.

Stankovic, V. (2005). Fenotipske i genotipske korelacije morfofizioloskih svojstava $i$ komponenti prinosa proteinskog suncokreta (Heliantus annuus L.). Novi Sad: Poljoprivredni fakultet.

Yan, W., Hunt, L.A., Sheng, Q., \& Szlavnics, Z. (2000). Cultivar evaluation and megaenvironment investigation based on the GGE biplot. Crop Sci., 40, 597-605.

Yan, W., Cornelius, P.L., Crossa, J., \& Hunt, L.A. (2001). Two types of GGE biplots for analyzing multi-environment trial data. Crop Sci., 41, 656-663.

Yan, W., \& Tinker, N.A. (2006). Biplot analysis of multi-environment trial data: Principles and applications. Can. J. Plant Sci., 86(3), 623-645. doi:10.4141/P05-169

\title{
Mega-sredine suncokreta u Srbiji prema GGE biplot analizi
}

\author{
Igor Balalić• Gordana Branković • Miroslav Zorić • Vladimir Miklič $\bullet$ \\ Siniša Jocić • Gordana Šurlan-Momirović
}

Sažetak: Analiza mega-sredina suncokreta sprovedena je prema podacima prinosa zrna 20 hibrida i 19 test lokaliteta tokom 2006. i 20 hibrida i 16 test lokaliteta tokom 2007. Kombinovani podaci obuhvatili su 15 hibrida i 9 test lokaliteta, zajedničkih za obe godine istraživanja, pri čemu je analizirano kao izbalansirani eksperiment. Analiza komponenti varijanse pokazala je da interakcija hibrid puta lokalitet objašnjava 2,74, 5,8 i 3,72 puta više varijacija nego hibrid na prinos zrna za 2006. i 2007. u kombinovanim podacima, tim redom, i ukazuje na potencijalno postojanje mega-sredina. Naši rezultati su pokazali postojanje dve mega-sredine u reonima gajenja suncokreta u Srbiji: (1) Kula Vitovnica, Aleksa Šantić, Sombor i (2) Rimski Šančevi, Kikinda. Zaključeno je da ako želimo da perspektivni hibridi suncokreta budu optimalno iskorišćeni, moraju biti drugačije obrađeni za dve utvrđene mega-sredine.

Ključne reči: hibridi, interakcija genotip $\times$ spoljna sredina, lokalitet, mega-sredina, prinos zrna, regresija lokaliteta, suncokret 